\title{
Asanoa iriomotensis sp. nov., isolated from mangrove soil
}

\author{
Tomohiko Tamura and Takeshi Sakane
}

Correspondence

Tomohiko Tamura

tamura-tomohiko@nite.go.jp

\author{
Biological Resource Center (NBRC), Department of Biotechnology, National Institute of \\ Technology and Evaluation, 2-5-8 Kazusakamatari, Kisarazu, Chiba 292-0812, Japan
}

The genus Asanoa was proposed by Lee \& Hah (2002) to accommodate actinomycetes with meso-diaminopimelic acid $\left(\mathrm{A}_{2} \mathrm{pm}\right)$ and $3-\mathrm{OH} \mathrm{A} \mathrm{A}_{2} \mathrm{pm}$ in the cell wall, $\mathrm{MK}-10\left(\mathrm{H}_{6}\right.$, $\mathrm{H}_{8}$ ) as the major menaquinone and fatty acid type $2 \mathrm{~d}$ and which belong to the family Micromonosporaceae by their 16S rRNA gene sequences. The genus was established with Asanoa ferruginea (basonym Catellatospora ferruginea Asano and Kawamoto 1986) and Asanoa ishikariensis (formerly 'Catellatospora ishikariense') and was distinguished from the genus Catellatospora by members of the latter genus displaying major menaquinone $\mathrm{MK}-10\left(\mathrm{H}_{4}\right)$ or $\mathrm{MK}-9\left(\mathrm{H}_{4}\right.$, $\mathrm{H}_{6}$ ) and fatty acid type $3 b$ (Lee \& Hah, 2002).

Mangroves are salt-adapted plants found along many of the world's tropical and subtropical coastlines (Dodd, 2000). In Japan, mangroves develop along estuaries in the subtropical zone, where sea water and river water mix. During a study of the diversity of actinomycetes that inhabit the mangrove zone, strain TT $97-02^{\mathrm{T}}$ was isolated from soil around the roots of the mangrove Bruguiera gymnorrhiza. Strain TT $97-02^{\mathrm{T}}$ formed spore chains borne on the tip of short sporophores arising directly from the agar surface. The isolate formed a monophyletic cluster with the members of the genus Asanoa and had fatty acid type $2 \mathrm{~d}$ and major menaquinone $\mathrm{MK}-10\left(\mathrm{H}_{6}, \mathrm{H}_{8}\right)$. This isolate represents a novel species of Asanoa, for which we propose the name Asanoa iriomotensis.

Strain TT $97-02^{\mathrm{T}}$ was isolated on humic acid-vitamin (HV)

Abbreviation: $A_{2}$ pm, diaminopimelic acid.

The GenBank/EMBL/DDBJ accession number for the 16S rRNA gene sequence of Asanoa iriomotensis TT $97-02^{\top}$ is AB112081.

A scanning electron micrograph showing sporulation of strain TT $97-02^{\top}$ is available as supplementary material in IJSEM Online. agar (Hayakawa \& Nonomura, 1987) by the yeast extract/ SDS method (Hayakawa \& Nonomura, 1989) from soil around the roots of B. gymnorrhiza growing along the Shiira River in Iriomote Island, Okinawa Prefecture, Japan. Freeze-dried cells for chemotaxonomic analyses were grown in yeast extract/glucose broth $(10 \mathrm{~g}$ yeast extract and $10 \mathrm{~g}$ D-glucose per litre distilled water, $\mathrm{pH} 7 \cdot 0$ ) on a rotary shaker at $28^{\circ} \mathrm{C}$. A. ferruginea NBRC $14496^{\mathrm{T}}$ and $A$. ishikariensis NBRC $14551^{\mathrm{T}}$ were used as reference strains.

Cultural and physiological characteristics were determined as described previously (Gordon et al., 1974; Seino et al., 1985; Shirling \& Gottlieb, 1966; Yokota et al., 1993). Morphology was observed by scanning electron microscopy as described previously (Tamura et al., 2000). Analyses of whole-cell sugar patterns, cell-wall amino acids, menaquinones, cellular fatty acids, isomers of $\mathrm{A}_{2} \mathrm{pm}$, acyl type of peptidoglycan, mycolic acid and DNA base composition were performed as described previously (Tamura et al., 1994). The microplate hybridization method developed by Ezaki et al. $(1988,1989)$ was applied with minor modifications to determine DNA relatedness (Tamura et al., 1999). PCR amplification and sequencing of the $16 \mathrm{~S}$ rRNA gene were performed as described previously (Tamura \& Hatano, 2001) with a model ABI PRISM 3100 Genetic Analyzer (Applied Biosystems) according to the manufacturer's protocol. Phylogenetic analysis of 16S rRNA gene sequences was performed as described previously (Tamura \& Hatano, 2001).

The isolate was a Gram-positive, non-acid-fast and aerobic organism with branched hyphae. A non-fragmenting substrate mycelium was formed. A 14-day-old culture grown on HV agar showed spore chains borne on the tip of short sporophores arising directly from the agar surface (see 
supplementary figure in IJSEM Online). Motile spores were not observed.

The isolate exhibited good growth on yeast extract-malt extract agar (ISP medium 2), moderate growth on oatmeal agar (ISP medium 3), poor growth on inorganic saltsstarch agar (ISP medium 4), glycerol-asparagine agar (ISP medium 5) and peptone-yeast extract-iron agar (ISP medium 6) and almost no growth on tyrosine agar (ISP medium 7). The isolate formed spore chains on water agar and HV agar, but not on yeast extract-malt extract agar, oatmeal agar, inorganic salts-starch agar, glycerol-asparagine agar, peptone-yeast extract iron agar or tyrosine agar.

Strain TT $97-02^{\mathrm{T}}$ hydrolysed starch, but did not reduce nitrate. It grew at 20 and $30^{\circ} \mathrm{C}$, but not at 15 or $37^{\circ} \mathrm{C}$. The isolate utilized (-)-D-mannitol, (+)-D-melibiose, $(+)$-Dmaltose, $(+)$-L-rhamnose, methyl $\alpha$-D-glucoside, $(+)$-Draffinose, $(+)$-D-galactose, $(+)$-D-mannose and glucose and grew weakly on $(+)$-L-arabinose and $(+)$-D-xylose, but did not utilize L-erythritol, adonitol, (+)-D-lactose, Linositol, D-sorbitol or dulcitol as sole carbon sources. The isolate did not grow on $4 \% \mathrm{NaCl}$. Hydrolysis of aesculin, decomposition of urea, utilization of sodium succinate, sodium oxalate, sodium malate and sodium citrate and growth on MacConkey agar were negative.

The cell walls contained meso- $\mathrm{A}_{2} \mathrm{pm}, \mathrm{D}$-glutamic acid, glycine and L-alanine, indicating that the peptidoglycan is type A1 $\gamma$ according to Schleifer \& Kandler (1972). The isolate contained xylose, mannose, galactose and glucose as whole-cell sugars, but arabinose was not detected. The major menaquinones were $\mathrm{MK}-10\left(\mathrm{H}_{6}\right)$ and $\mathrm{MK}-10\left(\mathrm{H}_{8}\right)$. The major cellular fatty acids were anteiso- $\mathrm{C}_{15: 0}(22 \cdot 3 \%)$, anteiso- $\mathrm{C}_{17: 0}(19 \cdot 6 \%)$, iso- $\mathrm{C}_{15: 0}(18 \cdot 0 \%), \mathrm{C}_{17: 0}(13 \cdot 6 \%)$ and iso- $\mathrm{C}_{16: 0}(12 \cdot 2 \%)$, and small amounts of iso- $\mathrm{C}_{17: 0}$, $\mathrm{C}_{16: 0}, \mathrm{C}_{18: 0}, \mathrm{C}_{15: 0}$ and iso- $\mathrm{C}_{14: 0}$ were also detected. Mycolic acids were absent. Phosphatidylethanolamine was detected, but phospholipids including unidentified glucosamine and phosphatidylcholine were not detected, corresponding to phospholipid type II of Lechevalier et al. (1981). The acyl type of cell-wall polysaccharides was acetyl. The G+C content of the genomic DNA was $69 \mathrm{~mol} \%$.
The 16S rRNA gene sequence was determined for strain TT 97- $02^{\mathrm{T}}$ (positions 28-1525 according to the Escherichia coli numbering system; Brosius et al., 1978). Positions at which secondary structures varied between strains and positions at which the sequence was not determined in some reference organisms were excluded from the analysis. The phylogenetic tree obtained by applying the neighbour-joining method to $K_{\text {nuc }}$ values is depicted in Fig. 1. 16S rRNA gene sequence analysis revealed that the isolate fell in the cluster of the family Micromonosporaceae and formed a monophyletic cluster with members of the genus Asanoa. The isolate was closely related to A. ferruginea and A. ishikariensis (96.9-97.1\% similarity). In a DNA-DNA hybridization study, strain TT $97-02^{\mathrm{T}}$ exhibited levels of DNA-DNA relatedness of $15-28 \%$ with $A$. ferruginea NBRC $14496^{\mathrm{T}}$ and A. ishikariensis NBRC $14551^{\mathrm{T}}$.

The previously known members of the genus Asanoa show poor sporulation that occurs only on tap water agar and glycerol/calcium malate agar (Asano \& Kawamoto, 1986; Lee \& Hah, 2002). Sporulation of strain TT $97-02^{\mathrm{T}}$ was not observed on richly nutritious media but developed well on water agar and HV agar. Chemotaxonomic characteristics and phylogenetic analysis based on 16S rRNA gene sequences indicated that the isolate is a member of the genus Asanoa. The isolate could be distinguished from the two known species, A. ferruginea and A. ishikariensis, by its low relatedness in DNA-DNA hybridization, its cellular fatty acid profile and the utilization of some carbon sources (Table 1). On the basis of the data presented above, we propose that strain TT $97-02^{\mathrm{T}}$ be classified in a novel species, Asanoa iriomotensis sp. nov.

\section{Description of Asanoa iriomotensis sp. nov.}

Asanoa iriomotensis (i.ri.o.mo.ten'sis. N.L. fem. adj. iriomotensis of Iriomote Island, Okinawa, Japan, the origin of the soil sample from which the type strain was isolated).

Spore chains borne on the tip of short sporophores arising directly from the agar surface develop on water agar and HV agar. Hydrolyses starch. Does not reduce nitrate. Grows at 20 and $30^{\circ} \mathrm{C}$, but not at 15 or $37^{\circ} \mathrm{C}$. Utilizes

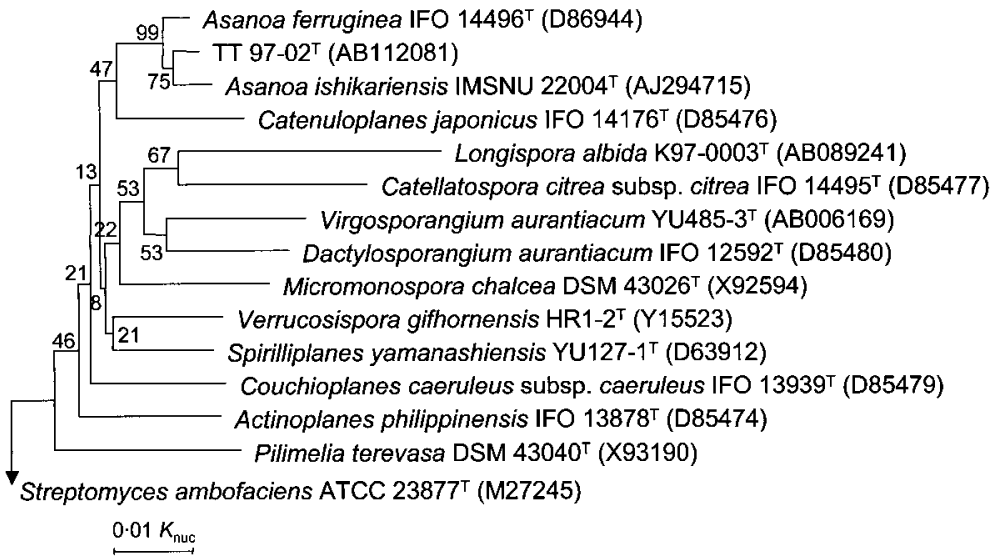

Fig. 1. Phylogenetic tree, based on the neighbour-joining method (Saitou \& Nei, 1987), derived from 16S rRNA gene sequences for members of the family Micromonosporaceae. Streptomyces ambofaciens ATCC $23877^{\top}$ was used as the root organism. Scale bar, $0.01 K_{\text {nuc }}$ in nucleotide sequences. Numbers on branches are confidence limits (expressed as percentages) estimated from a bootstrap analysis with 1000 replicates. 
Table 1. Diagnostic characteristics that differentiate Asanoa iriomotensis sp. nov. TT $97-02^{\top}$ from other members of the genus Asanoa

Data for reference species were taken from Lee \& Hah (2002). W, Weak growth.

\begin{tabular}{|c|c|c|c|}
\hline Characteristic & Strain TT $97-02^{\mathrm{T}}$ & A. ferruginea & A. ishikariensis \\
\hline Adonitol & - & + & + \\
\hline$(+)$-L-Arabinose & $\mathrm{W}$ & + & + \\
\hline Dulcitol & - & - & + \\
\hline Growth at $37^{\circ} \mathrm{C}$ & - & + & - \\
\hline
\end{tabular}

(-)-D-mannitol, $(+)$-D-melibiose, $(+)$-D-maltose, $(+)$-Lrhamnose, methyl $\alpha$-D-glucoside, $(+)$-D-raffinose, $(+)$-Dgalactose, $(+)$-D-mannose and glucose. Does not grow on L-erythritol, adonitol, (+ )-D-lactose, L-inositol, D-sorbitol or dulcitol. Phosphatidylethanolamine is present as the diagnostic phospholipid. Unsaturated fatty acids and 10methylated fatty acids are not detected. The fatty acid profile is characterized by significant amounts of anteiso- $\mathrm{C}_{15: 0}$, anteiso- $\mathrm{C}_{17: 0}$, iso- $\mathrm{C}_{15: 0}, \mathrm{C}_{17: 0}$ and iso- $\mathrm{C}_{16: 0}$. The $\mathrm{G}+\mathrm{C}$ content of genomic DNA of the type strain is $69 \mathrm{~mol} \%$. Habitat is soil.

The type strain is TT $97-02^{\mathrm{T}}\left(=\mathrm{NBRC} 100142^{\mathrm{T}}=\mathrm{DSM}\right.$ $44745^{\mathrm{T}}$ ).

\section{Acknowledgements}

The authors acknowledge a Grant-in-Aid for Scientific Research (C) (2) no. 11660326 from the Japan Society for the Promotion of Science. The authors are grateful to Drs Akira Nakagiri, Yasuyoshi Nakagawa, Izumi Okane and Kumiko Ueda-Nishimura for kind help.

\section{References}

Asano, K. \& Kawamoto, I. (1986). Catellatospora, a new genus of the Actinomycetales. Int J Syst Bacteriol 36, 512-517.

Brosius, J., Palmer, M. L., Kennedy, P. J. \& Noller, H. F. (1978). Complete nucleotide sequence of a $16 \mathrm{~S}$ ribosomal RNA gene from Escherichia coli. Proc Natl Acad Sci U S A 75, 4801-4805.

Dodd, R. S. (editor) (2000). Diversity and Function in Mangrove Ecosystems, Developments in Hydrobiology, vol. 145. Dordrecht: Kluwer Academic.

Ezaki, T., Hashimoto, Y., Takeuchi, N., Yamamoto, H., Liu, S.-L., Miura, H., Matsui, K. \& Yabuuchi, E. (1988). Simple genetic method to identify viridans group streptococci by colorimetric dot hybridization and fluorometric hybridization in microdilution wells. J Clin Microbiol 26, 1708-1713.

Ezaki, T., Hashimoto, Y. \& Yabuuchi, E. (1989). Fluorometric deoxyribonucleic acid-deoxyribonucleic acid hybridization in microdilution wells as an alternative to membrane filter hybridization in which radioisotopes are used to determine genetic relatedness among bacterial strains. Int J Syst Bacteriol 39, 224-229.
Gordon, R. E., Barnett, D. A., Handerhan, J. E. \& Pang, C. H.-N. (1974). Nocardia coeliaca, Nocardia autotrophica, and the nocardin strain. Int J Syst Bacteriol 24, 54-63.

Hayakawa, M. \& Nonomura, H. (1987). Humic acid-vitamin agar, a new medium for selective isolation of soil actinomycetes. J Ferment Technol 65, 501-509.

Hayakawa, M. \& Nonomura, H. (1989). A new method for the intensive isolation of actinomycetes from soil. Actinomycetologica 3, 95-104.

Lechevalier, M. P., Stern, A. E. \& Lechevalier, H. A. (1981). Phospholipids in the taxonomy of actinomycetes. Zentbl Bakteriol Parasitenkd Infektionskr Hyg I Abt Suppl 11, 111-116.

Lee, S. D. \& Hah, Y. C. (2002). Proposal to transfer Catellatospora ferruginea and 'Catellatospora ishikariense' to Asanoa gen. nov. as Asanoa ferruginea comb. nov. and Asanoa ishikariensis sp. nov., with emended description of the genus Catellatospora. Int J Syst Evol Microbiol 52, 967-972.

Saitou, N. \& Nei, M. (1987). The neighbor-joining method: a new method for reconstructing phylogenetic trees. Mol Biol Evol 4, 406-425.

Schleifer, K. H. \& Kandler, O. (1972). Peptidoglycan types of bacterial cell walls and their taxonomic implications. Bacteriol Rev 36, 407-477.

Seino, A., Arai, M., Enokida, R., Okazaki, T. \& Furuichi, A. (1985). Identification Manual of Actinomycetes. Tokyo, Japan: The Society for Actinomycetes.

Shirling, E. B. \& Gottlieb, D. (1966). Methods for characterization of Streptomyces species. Int J Syst Bacteriol 16, 313-340.

Tamura, T. \& Hatano, K. (2001). Phylogenetic analysis of the genus Actinoplanes and transfer of Actinoplanes minutisporangius Ruan et al. 1986 and 'Actinoplanes aurantiacus' to Cryptosporangium minutisporangium comb. nov. and Cryptosporangium aurantiacum sp. nov. Int J Syst Evol Microbiol 51, 2119-2125.

Tamura, T., Nakagaito, Y., Nishii, T., Hasegawa, T., Stackebrandt, E. \& Yokota, A. (1994). A new genus of the order Actinomycetales, Couchioplanes gen. nov., with descriptions of Couchioplanes caeruleus (Horan and Brodsky 1986) comb. nov. and Couchioplanes caeruleus subsp. azureus subsp. nov. Int J Syst Bacteriol 44, 193-203.

Tamura, T., Hayakawa, M. \& Hatano, K. (1999). Sporichthya brevicatena sp. nov. Int J Syst Bacteriol 49, 1779-1784.

Tamura, T., Suzuki, S. \& Hatano, K. (2000). Acrocarpospora gen. nov., a new genus of the order Actinomycetales. Int J Syst Evol Microbiol 50, 1163-1171.

Yokota, A., Tamura, T., Hasegawa, T. \& Huang, L. H. (1993). Catenuloplanes japonicus gen. nov., sp. nov., nom. rev., a new genus of the order Actinomycetales. Int J Syst Bacteriol 43, 805-812. 